\title{
PRIMARY TEACHERS' PROFESSIONAL TRAINING \\ IN THE SYSTEM OF POSTGRADUATE EDUCATION IN THE LIGHT OF DIFFERENTIATING TEACHING: IRISH EXPERIENCE
}

\begin{abstract}
Different information sources, namely National Strategy for Higher Education to 2030 (Ireland), Introduction to Primary School Curriculum (1999), (Ireland), Primary Professional Development Service - Differentiation in Action, Ireland's official postgraduate study website, the Strategic Plan 2012-2016 of Mary Immaculate College, Limerick University), have been studied. The mission of primary education in the light of differentiating teaching has been indicated. Main aspects of differentiating teaching have been highlighted. The correspondence between differentiating teaching foundations and primary school curriculum has been proved. Irish experience in professional training of future primary teachers in the system of postgraduate education in the light of differentiating teaching has been analyzed. Due to theoretical analysis of Professional Master of Education (Primary Teaching) (PME) postgraduate course's aims the priority tasks of future primary teachers have been defined. Peculiarities of the postgraduate course of the Professional Master of Education (Primary Teaching) at Mary Immaculate College, University of Limerick have been justified. Positive aspects of Irish experience in postgraduate education system, in particular professional training of primary teachers, have been defined. Perspectives for the Ukrainian postgraduate system as for professional training of primary teachers have been outlined.

Key words: professional training, primary teacher, primary school, primary school curriculum, postgraduate education, differentiating teaching, Irish experience.

\section{INTRODUCTION}

Dr. Caroline Hussey, former Register and Deputy President of University College Dublin (UCD), claims that "education is an important factor both in the day-to-day development of the child and in contributing to the personal, social, cultural and economic fulfillment of the future adult" (Primary School Curriculum (Introduction), 1999).

Primary school is the most essential period of personality's development, as primary students comprehend basic foundations of sciences by trial and error and learn to be true members of society. However, children are different and that is why teaching requires being child-oriented to meet their needs. Primary teachers are called to open their potential applying flexible approaches. Therefore, primary teachers must possess appropriate knowledge and skills to accomplish this goal. In other words, the professional training of primary teachers deserves special attention.

According to the Irish National Strategy for Higher Education to 2030 "the rise in postgraduate education over the last decade has been very significant" as more and more
\end{abstract}


people are "seeking further professional development and new skills" (National Strategy for Higher Education to 2030, 2011).

Ireland's official postgraduate study website launched by the Association of Higher Education Careers Services and GTI Ireland finds 102 search results dedicated to primary education (Ireland's Official Postgraduate Study Website, 2015) that justifies the increasing demand for both future primary teachers and graduates' striving for professional development.

So, it is necessary to study foreign experience in postgraduate education system of primary teachers, as positive aspects of such experience can be taken into account to improve postgraduate education system in Ukraine, both in general and concerning professional training of primary teachers, in particular in the light of differentiating teaching and learning.

\section{THE AIM OF THE STUDY}

The aim of the paper consists in the following:

1) to study Irish experience of primary teachers' professional training in the system of postgraduate education in the light of differentiating teaching and learning;

2) to define positive aspects of such experience with their further implementation into postgraduate education system of Ukraine, in particular professional training of primary teachers.

\section{THEORETICAL FRAMEWORK AND RESEARCH METHODS}

Theoretical basis of our research consists of National Strategy for Higher Education to 2030 (Ireland) as prospects of Irish higher education development for the next decades have been outlined there; Introduction to Primary School Curriculum (1999), (Ireland) as it was of scientific interest to draw parallels between the curriculum and the goals of postgraduate programmes set by higher educational establishments; Primary Professional Development Service - Differentiation in Action as it is of great importance to define peculiarities of differentiating teaching; Ireland's official postgraduate study website launched by the Association of Higher Education Careers Services and GTI Ireland as it is important to find out offer and demand concerning the professional training of primary teachers in postgraduate education; the Strategic Plan 2012-2016 of Mary Immaculate College, Limerick University for defining the college's mission and vision of postgraduate training; information on Professional Master of Education (Primary Teaching) postgraduate programme acquired from the official website of Mary Immaculate College, Limerick University for studying the experience and defining its positive aspects for their further implementation into the professional training of primary teachers in Ukraine.

Such methods as synthesis, theoretical analysis, generalisation, systematisation and prognosis resulted in the conclusion and the perspectives of further scientific researches have been used in the study.

\section{RESULTS}

Of our scientific interest became The Primary School Curriculum of Ireland presented in 1999 by the National Council for Curriculum and Assessment (NCCA), being "the culmination of many years of development and planning that involved all the partners and interests in primary education" (Primary School Curriculum, 1999). While performing theoretical analysis of the paper we defined main areas of The Primary School Curriculum of Ireland: the child's uniqueness; the child and society; education and the society; the child's development and learning how to learn.

So, the child's uniqueness comes out on top that proves utmost interest of Irish government in educating self-contained, fully-developed personality of future adults. 
Certain defining features of the curriculum, namely a focus on learning, a broad and balanced curriculum, a detailed statement of content, assessment as an integral part of teaching and learning and the importance of planning are noteworthy (Primary School Curriculum, 1999). First of all, key words of the curriculum's abovementioned features are individual child, differing needs, identification of children's needs, flexibility, different approaches, unique requirements that justifies the direction towards differentiating teaching and learning that is relevant to our study. Second of all, relying on these features we have chosen the experience of Mary Immaculate College, University of Limerick, Ireland as theoretical basis for our study since it provides postgraduate programme of primary teachers' professional training and its curriculum fully corresponds with the goals and objectives of Primary School Curriculum towards pupils' uniqueness and individual abilities development.

Mary Immaculate College, founded in 1898, sees its mission in promoting "excellence in teaching, learning, and research at undergraduate and postgraduate levels" and "strives to provide an environment where all have freedom and opportunity to achieve their full potential" (Strategic Plan 2012-2016 of Marry Immaculate College, 2012).

According to the college's Strategic Plan 2012-2016 postgraduate education is seen as an essential institution that has a great impact on high value economy development that is why main goals are: expanding range of opportunities for postgraduate study and provision increasing at doctoral level; postgraduate management framework review; postgraduate student experience improving; enhancing postgraduate students' participation in research and publishing (Strategic Plan 2012-2016 of Marry Immaculate College, 2012).

Thus, it will be logical to present information on the peculiarities of the postgraduate course of the Professional Master of Education (Primary Teaching) at Mary Immaculate College, University of Limerick.

The Professional Master of Education (Primary Teaching) (PME) being two year, full-time postgraduate teacher education programme is aimed at qualifying graduates as primary teachers.

According to Diane Heacox, Associate Professor of Education at St. Catherine University in St. Paul, Minnesota, differentiation implies "changing the pace, level, or kind of instruction you provide in response to individual learners' needs, styles or interests" (Heacox, 2002).

PME is focused on practice whereas students have possibilities to critically evaluate gained experiences, find new understandings as well as integrate educational theory and practice with the help of research applications.

Students are equipped with necessary competencies that will help them to apply flexible approaches to differentiating teaching thus satisfying primary students' different needs, because "to differentiate effectively and support individual and diverse students in the classroom, the teacher is required to be flexible in their approach in order to adjust:

what the pupils will learn (content); how the pupils will learn (process); how they will demonstrate their learning (product)" (Primary Professional Development Service Differentiation in Action, 2015).

Within the defined course there are three research methods modules and they are to provide students with "critical introduction to the principal methods in educational research; identify educational research issues and questions; consider appropriate methods of their investigation" (Professional Master of Education (Primary Teaching), 2015). 
Having performed theoretical analysis of PME postgraduate course's aims, we defined the tasks future professionals are to accomplish:

$\checkmark$ promoting and maintaining a strong commitment to education and teaching as well as the quality of their pupils' educational experiences;

$\checkmark$ assistance in unlocking and realizing pupils' potential;

$\checkmark$ value of their different identities (learners, teachers, researchers, future leaders);

$\checkmark$ promoting innovative, child-centered, flexible environment;

$\checkmark$ developing their personal and professional qualities such as responsibility, creativity, risk-taking and innovation with further contributing to Irish society sustainable development under the conditions of modern tendencies (rapid economic development, integration processes, social transformations and transfer to information society);

$\checkmark$ recognition and appreciation of the difference.

So, as one can see the tasks set before future primary teacher students are connected with pupils' uniqueness as well as their different needs and thus professional training is aimed at fostering differentiating teaching skills and flexible approaches oriented towards pupils' sustainable development and their potential realisation.

Speaking about the programme itself, PME course is divided into two years, consequently into four semesters.

During the first semester of the first year students are provided with strong foundation in many curricular areas, foundation disciplines, research methods and are introduced to School Placement. School Placement is "a critical part of initial teacher education (ITE). It allows the student teacher to experience teaching and learning in a variety of contexts, and to participate in school life in a way that is structured and supported" (The Teaching Council, 2012). Students are taught to play different roles, such as teacher and learner, leader and researcher. In such a way they learn to be the facilitators of the educational process to provide pupils with differentiated learning experiences, organize them for learning and use time flexibly so they are able to suit pupils' needs. According to Diane Heacox, "as a teacher who differentiates instruction, you become both a facilitator and a collaborator" (Heacox, 2002).

Due to integrating subject-specific pedagogies and modules aimed at studying contemporary educational issues based on both campus and school learning, it is possible for students to fully comprehend teaching and learning.

The curriculum of the second semester is built on the knowledge, experience and skills obtained during the previous semester. It should be mentioned that the second semester is primarily focused on practice as it includes prolonged school placement offering students to apply gained knowledge to practice and a summer school programme that is an integral part of the first year of this Master's programme. Tréimhse Foghlama sa Ghaeltacht or New Gaeltacht Placement is also a part of the abovementioned summer programme that implies residential Irish language courses. The aims of the Gaeltacht Placement are: to enhance students' communicative competence, in the context of their future role as teachers of Irish and of other subjects through the medium of Irish, and as users of Irish in the school community; to enhance their knowledge and understanding of the life and culture of the Gaeltacht; to deepen their understanding of the sociolinguistic realities of bilingual Gaeltacht communities; to be an enjoyable experience, which enhances student teachers' love of Irish as a language and their confidence in speaking it (Report of the Gaeltacht Placement Working Group to the Teaching Council, 2012).

After returning to the campus students are to complete an oral Irish examination. It should be mentioned that two online modules must be completed. During the first module, 
called Leadership and Policy, students gain extensive experience of educational research through fundamental theories as well as aspects of leadership and policy exploration. During the second module, namely Research Methods, student study research principles, theories and approaches and complete students' research ethics application.

The second year consequently is based on the knowledge and skills, gained during the first year of learning and involves a taught module and a specific school placement. Special attention is paid to the multi-faceted nature of the teacher and teacher profession role as the third semester draws a parallel between teaching, learning and research. During the third semester students are to develop their research proposal by means of data collection and analysis. Students work individually, are entitled to have supervisors and have a possibility to expertise in the chosen field. Educational research reports are to be submitted during the fourth semester.

The fourth semester, in its turn, is dedicated to prolong school placement aimed at applying knowledge and skills acquired during the previous semesters. It is important to note that the professional portfolio's completion and presentation is considered to be a key feature as it provides students with an opportunity to link practice with theory, fully comprehend subject matter and be ready to participate in discussing teaching and learning. It also enables students to structurise, document and reflect their own thoughts, opinions, experiences, achievements they have obtained during their teacher education programme.

As for the further progression, in case of the programme's successful completion, students will be registered by the Teaching Council and entitled to professional performance in Irish primary schools.

To sum up, students of PME postgraduate course are provided with well-structurised and practice-oriented learning programme, are taught to apply flexible approaches in the light of differentiating teaching, acquire extensive experience in teaching and gain essential skills concerning further professional research. Therefore, future primary teachers have great prospects of being in demand on the labour market.

\section{CONCLUSIONS}

Thus, we have studied Irish experience of primary teachers' professional development in the system of postgraduate education in the light of differentiating teaching and learning.

Having performed theoretical analysis of different information sources, namely Introduction to Primary School Curriculum (1999), (Ireland), Primary Professional Development Service - Differentiation in Action, we have concluded that primary school curriculum is based on the principles of differentiating teaching that is the instruction aimed at meeting pupils' different needs by means of various flexible approaches to open their potential. Search results of Ireland's official postgraduate study website launched by the Association of Higher Education Careers Services and GTI Ireland have proved that there is an increasing demand for both future primary school teachers and graduates' striving for professional development. As theoretical basis for our study the experience of Mary Immaculate College, University of Limerick, Ireland has been chosen since its postgraduate programme of primary teachers' professional training and its curriculum fully correspond with the goals and objectives of Primary School Curriculum towards pupils' uniqueness and individual abilities development. The programme tasks set before future primary teacher students are connected with pupils' uniqueness as well as their different needs and thus professional training is aimed at fostering differentiating teaching skills and flexible approaches oriented towards pupils' sustainable development and their potential realisation. Programme is practice-centered, therefore students have possibilities to apply obtained 
knowledge, skills and abilities to realize their multi-faceted roles within the school environment (teacher, learner, leader, researcher). Special attention deserves Tréimhse Foghlama sa Ghaeltacht (New Gaeltacht Placement) since such language courses encourage future primary students to foster their native language and therefore further develop their pupils' respect to the language that consequently leads to the strengthening and development of the society they belong to. Research skills obtained by students during their study will considerably help them in the professional field and will encourage them to further scientific research.

Thus, the implementation of the abovementioned positive aspects of Irish experience into postgraduate system of Ukraine will contribute to the improvement of primary teachers' postgraduate professional training in Ukrainian higher educational establishments, primary school system of Ukraine as well as the sustainable development of Ukrainian society.

\section{REFERENCES}

1. Department of Education and Skills of Ireland. (1999). Primary School Curriculum (Introduction). Dublin: The Stationery Office, p. 80. Retrieved 13.02.2015 from : http://www.craggaghns.ie/files/Introduction.pdf.

2. Heacox, D. (2002). Differentiating Instruction in the Regular Classroom: How to Reach and Teach All Learners. Minneapolis, Minnesota : Free Spirit Publishing, p. 164.

3. Ireland's Official Postgraduate Study Website. (2015). Retrieved 14.02.2015 from : http://www.mic.ul.ie/presidentsoffice/Documents/Strategic\%20Plan\%202012 2016.pdf

4. Marry Immaculate College, University of Limerick. (2015). Professional Master of Education (Primary Teaching). Retrieved 13.02.2015 from : http://www.mic.ul.ie/postgradstudies/prospectivestudents/Pages/GraduateDiplomainEducation.a spx.

5. Marry Immaculate College, University of Limerick. (2012). Strategic Plan 20122016 of Marry Immaculate College. Retrieved 14.02.2015 from http://www.mic.ul.ie/presidentsoffice/Documents/Strategic\%20Plan\%202012-2016.pdf.

6. National Strategy for Higher Education to 2030. (2011). Report of the Strategy Group. Dublin : Department of Education and Skills, p. 130. Retrieved 15.02.2015 from : http://www.cit.ie/contentfiles/DES_Higher_Ed_Main_Report.pdf.

7. Primary Professional Development Service - Differentiation in Action (2015). Retrieved 15.02.2015 from : http://www.pdst.ie/sites/default/files/Session\%202\%20\%20Dif ferentiation\%20Resource\%20_0_0.pdf.

8. The Teaching Council (2012). Report on the Gaeltacht Placement Working Group to the Teaching Council. Retrieved 14.02.2014 from : http://www.teachingcouncil.ie/_fileupload/Teacher\%20Education/Gaeltacht\%20Placement/ GaeltachtPlacementen.pdf. 